\title{
PERANCANGAN MEDIA KAMPANYE TENTANG PENCEGAHAN BUNUH DIRI
}

\author{
Nimas Sekararum ${ }^{1}$, Bernardus Andang Prasetya Adiwibawa ${ }^{2}$ \\ ${ }^{1,2}$ Program Studi Desain Komunikasi Visual, FIK, Universitas Dian Nuswantoro \\ 199.nimassekar@gmail.com \\ 2 andangprast@dsn.dinus.ac.id
}

\begin{abstract}
Abstrak
Tindakan bunuh diri atau keinginan untuk itu, terjadi pada ranah psikologis, dan karenanya membutuhkan bantuan profesional kesehatan mental seperti psikiater atau psikolog. Akan tetapi, jumlah penderita yang potensial melakukan tindak bunuh diri tidak sebanding dengan jumlah tenaga profesional kesehatan mental. Kehadiran komunitas-komunitas yang saling mendukung dalam ranah kesehatan mental, menjadi hal penting untuk mengatasi kurangnya akses terhadap bantuan kesehatan mental. Perancangan isi media sosial ini dibuat berbasis penelitian yang dilakukan secara kualitatif dengan analisis kerangka Robert N. Entman sebagai alatnya. Perancangan ini bertujuan untuk membuat masyarakat memahami dinamika pikiran dan perasaan seseorang yang ingin bunuh diri, sehingga mereka bisa turut melakukan pencegahan bunuh diri.
\end{abstract}

Keywords: desain; media kampanye; instagram; bunuh diri; framing,

\begin{abstract}
The act of suicide, or the desire to do so, occurs in the psychological realm and thus requires the help of a mental health professional such as a psychiatrist or psychologist. However, the number of potential sufferers to commit suicide is not proportional to the number of mental health professionals. The presence of communities that support each other in the realm of mental health is significant to overcome the lack of access to mental health assistance. The design of social media content based on research conducted qualitatively with the framing analysis of Robert $\mathrm{N}$. Entman as a tool. This design aims to make people understand the dynamics of the thoughts and feelings of someone who wants to commit suicide so that they can participate in suicide prevention.
\end{abstract}

Keywords: design, campaign media, instagram, suicide, framing

\section{PENDAHULUAN}

Indonesia, menempati urutan ke-8 kasus bunuh diri terbanyak di dunia. Pernyataan ini dikemukakan oleh dr. Titah Rahayu, Sp.K.J, dalam wawancara untuk www.biem.co (Yusdiansyah, 2018). Dalam wawancara itu, dr. Titah juga menyebutkan data yang dilansir dari Biro Pusat Statistik, bahwa pada tahun 2015 ada 5 propinsi dengan kasus bunuh diri terbanyak, yaitu; Jawa Tengah (331 kasus), Jawa Timur (119), Bali (96), DI Yogyakarta (59), Jawa Barat (51) dan DKI Jakarta (31).

Orang melakukan bunuh diri, menurut dr. Titah disebabkan adanya keyakinan yang salah mengenai pilihan mati sebagai hal terbaik untuk menyelesaikan masalah hidup.

Pendapat dr. Titah ini senada dengan kajian yang dilakukan oleh Dirgayunita yang menyebutkan bahwa depresi merupakan salah satu penyebab utama kejadian bunuh diri (Dirgayunita, 2016). Mukarromah dan Nuqul, dalam simpulan kajiannya juga menyoroti hal yang sama, bahwa tindakan bunuh diri atau keinginan untuk itu, terjadi pada ranah psikologis, dimana ego yang lemah, gagal membelokkan agresi pada objek diluar dirinya (Mukarromah and Nuqul, 2014).

dr. Jiemi Ardian, Sp.KJ di akun youtube pribadinya, ada cara untuk mencegah upaya bunuh diri, yaitu bantuan dari kalangan 
profesional seperti psikiater atau psikolog (Ardian, 2019). Namun, jumlah penderita tidak sebanding dengan jumlah tenaga profesional kesehatan mental.

Oleh karena itu, kehadiran komunitaskomunitas yang saling mendukung dalam ranah kesehatan mental, menjadi hal penting untuk mengatasi kurangnya akses terhadap bantuan kesehatan mental utamanya untuk kaum yang rentan melakukan upaya bunuh diri. Perancangan ini diarahkan sebagai dukungan komunikasi visual dalam kampanye pencegahan bunuh diri.

\section{METODE}

Penelitian ini berada pada ranah penelitian untuk perancangan (Research for Design) sebagaimana dinyatakan oleh Lois Frankel dan Martin Racine (Frankel and Racine, 2010). Sedangkan tahapan perancangan ini mengikuti peta jalan perancangan Bryan Lawson sebagaimana diikuti oleh Setyanto dan Adiwibawa (Setyanto and Adiwibawa, 2018) (Setyanto and Adiwibawa, 2019). Bagannya adalah sebagai berikut:

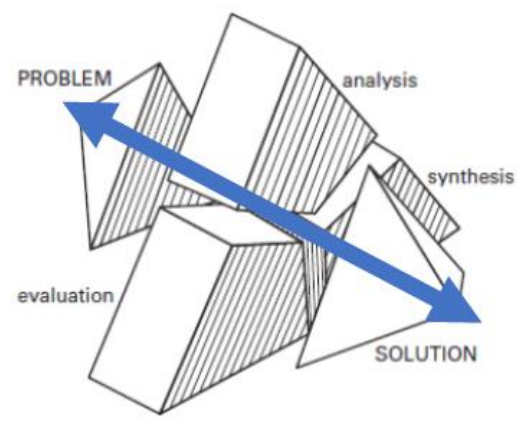

Gambar 1 : Peta jalan perancangan Bryan Lawson

Tahap pertama adalah memahami permasalahan desain; dalam hal ini adalah isu mengenai bunuh diri dan bagaimana pencegahannya. Pada tahap ini data terutama diperoleh melalui kajian kepustakaan dan wawancara dengan beberapa pihak; profesional kesehatan mental, pegiat komunitas dan informan.

Tahap analisis, sintesis dan evaluasi dilakukan dengan menseleksi isu penting dari fenomena melalui model analisis framing Robert. N. Entman (Damayanti, Putra and Mayangsari, 2016). Sementara pengembangan visual media kampanye dimulai dengan menetapkan fokus kampanye (what to say) dari hasil analisis framing dan mengelaborasi kemungkinan wujud visualnya (how to say) berdasar elemen dan prinsip desain.

Tahap terakhir adalah penyempurnaan media kampanye (finishing) yang dalam perencanaan ini diwujudkan dalam desain isi (content) media sosial instagram, buku cetak, dan beberapa pernak-pernik kampanye.

\section{HASIL DAN PEMBAHASAN}

\section{Bunuh Diri dan Pencegahannya}

Angka bunuh diri di Indonesia cukup tinggi; menempatkan Indonesia pada peringkat ke-8 negara dengan angka bunuh diri tertinggi. Data yang diperoleh menunjukkan bahwa ratarata 6,03 orang per 100.000 penduduk di Indonesia melakukan bunuh diri setiap tahunnya.

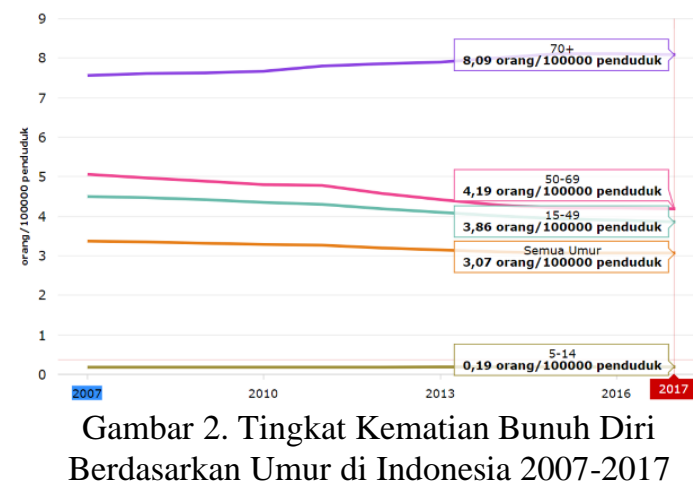

Menurut Mukarromah dan Nuqul, meski sampai saat ini, bunuh diri belum bisa dipastikan akar masalahnya secara spesifik, namun secara umum, bunuh diri disebabkan oleh kombinasi faktor yang saling berkaitan dan bersamaan, sehingga memunculkan keinginan bunuh diri. Faktor itu berupa faktor intrinsik dan ekstrinsik. Faktor intrinsik adalah dorongan dari dalam diri penderita, seperti kondisi psikologis yang sedang tidak seimbang, atau munculnya keinginan lari untuk menghentikan rasa sakit yang dirasakan. Faktor ekstrinsik adalah dorongan dari luar diri penderita, seperti adanya permasalahan yang dihadapi, misalnya mengalami kesulitan keuangan (Mukarromah and Nuqul, 2014).

Terkait dengan faktor ekstrinsik, Benny Prawira Siauw dalam wawancara dengan tirto.id mengatakan bahwa sejauh ini masyarakat tidak sensitif apabila ada seseorang 
yang sedang mengeluhkan kondisi jiwa yang berpotensi bunuh diri. Bahkan posisi orang yang punya kecenderungan bunuh diri, kata dia, masih mendapat stigma dari masyarakat, terutama saat menyampaikan kondisi yang mengarah ke bunuh diri melalui media sosial (Ramadhan, 2019).

Menurut Benny, dalam wawancara tersebut, sebenarnya masih ada kesempatan sesorang untuk mencegah upaya bunuh diri dari orang lain yaitu dengan merangkul mereka lewat komunikasi langsung maupun di media sosial. Kemudian, seseorang yang potensial melakukan bunuh diri, perlu didampingi untuk melakukan konsultasi kepada psikiater atau psikolog.

Pendapat Benny tersebut didukung dengan informasi yang diperoleh secara langsung oleh penulis dari dua praktisi kesehatan mental, Bianglala Andriadewi, M.Psi., Psikolog dan dr. Jiemi Ardian, Sp.KJ. Membuat ruang bebas stigma dan stereotype adalah hal yang perlu dilakukan. Hal lain yang dikemukakan keduanya adalah kurangnya kepekaan masyarakat akan ciri-ciri seseorang yang potensial melakukan upaya bunuh diri.

Di sisi lain, Bianglala menunjukkan bahwa jumlah tenaga profesional di bidang kesehatan mental, masih terbatas. Di seluruh Indonesia hanya ada 600-800 psikiater dan sekitar 1150 psikolog yang persebarannya masih terpusat di Pulau Jawa. Dari sejumlah itu, psikolog yang berprofesi sebagai psikolog klinis juga cukup rendah; proses pendidikan yang cukup sulit, serta harus menghadapi orang sakit untuk membantunya sembuh, menjadi salah satu alasannya.

Urgensi untuk mencegah seseorang melakukan upaya bunuh diri menjadi hal penting, namun kurangnya layanan atau ketersediaan tenaga profesional di bidang kesehatan mental adalah masalah tersendiri. Beruntung, di kalangan masyarakat muncul kelompok-kelompok, dengan dukungan beberapa profesional dalam kesehatan mental, yang mengabdikan diri untuk menjadi pendamping siapa saja yang membutuhkan layanan kesehatan mental; termasuk bagi orang yang potensial melakukan upaya bunuh diri. Salah satu kelompok tersebut adalah Ijinkan Dirimu.

Ijinkan Dirimu, banyak melakukan kegiatan bimbingan dan konseling, serta kampanye-kampanye kesehatan mental kepada masyarakat. Hal ini dilakukan mengingat bahwa masih rendahnya kesadaran masyarakat akan hubungan antara kesehatan mental dengan upaya bunuh diri. Sementara di sisi lain, masyarakat juga tidak terlalu peka akan ciri-ciri orang yang potensial melakukan upaya bunuh diri.

\section{Analisis Framing atas Isu Bunuh Diri}

Secara singkat, analisis framing yang penulis lakukan dapat dilihat dalam matriks framing berikut ini:

Tabel 1. Analisis Framing atas Isu Bunuh Diri

\begin{tabular}{|c|c|}
\hline $\begin{array}{l}\text { Define } \\
\text { Problem }\end{array}$ & $\begin{array}{l}\text { - Indonesia menempati urutan ke- } 8 \\
\text { negara di dunia yang tertinggi tingkat } \\
\text { bunuh dirinya } \\
\text { - Perilaku bunuh diri disebabkan oleh } \\
\text { faktor internal dan eksternal dalam } \\
\text { ranah psikologis }\end{array}$ \\
\hline Diagnose Cause & $\begin{array}{l}\text { Masyarakat terdekat dari seseorang } \\
\text { yang potensial melakukan upaya } \\
\text { bunuh diri, cenderung tidak sensitif } \\
\text { pada ciri-ciri psikologis yang muncul } \\
\text { - Masyarakat terdekat dari seseorang } \\
\text { yang potensial melakukan upaya } \\
\text { bunuh diri, tidak memiliki } \\
\text { pengetahuan yang cukup untuk } \\
\text { mencegah seseorang melakukan } \\
\text { upaya bunuh diri } \\
\text { - Kurangnya tenaga profesional dalam } \\
\text { bidang kesehatan mental dibanding } \\
\text { jumlah penduduk dan sebaran } \\
\text { geografis yang ada }\end{array}$ \\
\hline $\begin{array}{c}\text { Make Moral } \\
\text { Judgment }\end{array}$ & $\begin{array}{l}\text { - Seseorang dengan keinginan bunuh } \\
\text { diri diharapkan tetap berani mencari } \\
\text { pertolongan ke profesional kesehatan } \\
\text { mental, sekalipun tidak didukung oleh } \\
\text { orang sekitar. } \\
\text { - Masyarakat perlu membangun kondisi } \\
\text { yang mendukung, sehingga lebih } \\
\text { optimal dalam pencegahan bunuh diri, } \\
\text { antara lain manciptakan ruang yang } \\
\text { nyaman bebas stigma. } \\
\text { - Negara diharapkan memberikan } \\
\text { kecukupan layanan untuk } \\
\text { penduduknya di bidang kesehatan } \\
\text { mental }\end{array}$ \\
\hline
\end{tabular}




\begin{tabular}{|c|l|}
\hline & - Mengingat urgensi untuk melakukan \\
& upaya pencegahan bunuh diri, \\
& beberapa kelompok masyarakat \\
dengan dukungan profesional di & dalamnya membentuk komunitas dan \\
& melakukan kampanye-kampanye \\
pencegahan & \\
- Untuk keperluan kampanye tersebut, & perlu dukungan media kampanye \\
Treatment & yang tepat. \\
& - Pokok-pokok materi kampanye adalah \\
& tentang; ruang yang nyaman bebas \\
& stigma, kepekaan dan kepedulian \\
& sesama, tanpa penghakiman dan \\
& stereotyping, ajakan untuk bersedia \\
& menjadi pendampingan dalam \\
& mencari pertolongan pada profesional \\
kesehatan mental
\end{tabular}

\section{Komunitas Ijinkan Dirimu dan Kampanye Pencegahan Bunuh Diri}

Ijinkan Dirimu adalah komunitas yang berfokus pada edukasi serta layanan kesehatan mental untuk meningkatkan kualitas kesehatan mental masyarakat. Ijinkan Dirimu percaya bahwa untuk mewujudkan kesehatan mental yang baik, dibutuhkan kolaborasi dari berbagai pihak termasuk profesi kesehatan seperti psikiater dan psikolog.

Ijinkan Dirimu dibentuk oleh dr. Jiemi Ardian, Sp.KJ, bersama Reza Krisnadi Pratama, S.Psi dan Amalia Paravoti, S.Psi yang memiliki kepedulian serupa untuk membentuk komunitas lintas profesi tenaga kesehatan mental. Komunitas ini bisa dijangkau melalui nomor seluler: +6285726109109 dan di akun instagram: Instagram.com/ijinkandirimu.id.

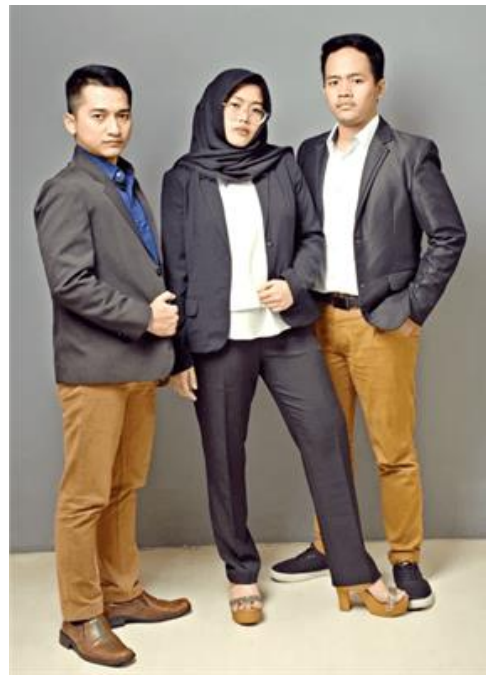

Gambar 3 : Para pendiri Ijinkan Dirimu; paling kiri dr. Jiem Ardian, Sp.KJ.
Meski tidak membatasi usia untuk dilayani dalam konsultasi kesehatan mental, data di Ijinkan Dirimu menunjukkan bahwa sebagian besar penderita gangguan mental yang dilayani, berkisar pada usia 15-29 tahun.

Oleh karena itu, selama ini, Ijinkan Dirimu banyak menyebarkan sosialisasi programnya melalui isi (content) media sosial mereka. Sementara secara pribadi dr. Jiem Ardian, Sp.KJ juga memiliki kanal youtube dan situs jejaring pribadi.

\section{Strategi Visual Media Kampanye}

Apa yang ingin dikatakan dari isi media sosial adalah bahwa keinginan untuk bunuh diri adalah masalah kesehatan mental, dan stigma negatif juga stereotype atas itu haruslah ditinggalkan. Pesan tersebut disampaikan dengan kalimat dan ilustras, yang dirancang sedemikian rupa dalam bentuk facing pages (menyerupai halaman buku) yang menggambarkan lembaran-lembaran hidup dan mental seseorang

Copywriting atau naskah kampanye yang digunakan berisi ungkapan realitas yang terjadi pada diri seseorang yang ingin bunuh diri. Ungkapan itu diperoleh dari wawancara dengan para penyintas kesehatan mental yang pernah berupaya bunuh diri. Realitas inilah diungkap untuk melawan stigma dan stereotype yang selama ini dianggap benar oleh masyarakat. Ilustrasi yang digunakan adalah gambar-gambar yang mewakili copywriting tersebut.

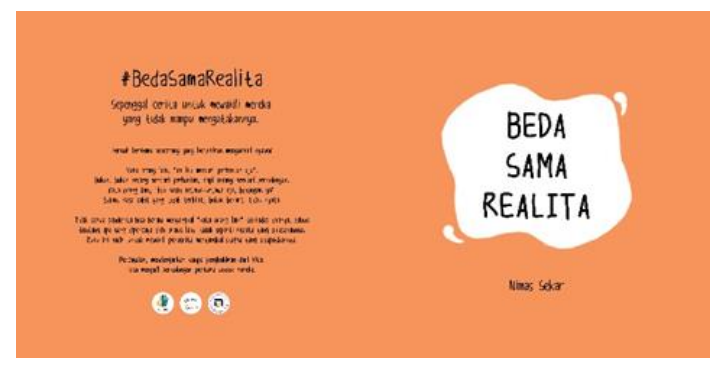

Gambar 4 : Desain halaman awal untuk isi instagram

Nuansa visual media kampanye yang dirancang adalah rasional-emosional. Maksudnya rasional dalam arti menampilkan fakta sebenarnya, dan emosional dalam tujuan menyentuh perasaan yang menyaksikan. Oleh karena itu, realitas yang diungkap dari para 
penyintas diberi ilustrasi untusk menguatkan pesan.

Ilustrasi yang digambarkan dibuat dengan dominasi warna-warna pastel. Warna ini dipilih karena mempunyai karakter yang tenang, lembut, dan tidak terlalu silau di mata jika dilihat melalui layar gawai seperti ponsel, tab, atau komputer.

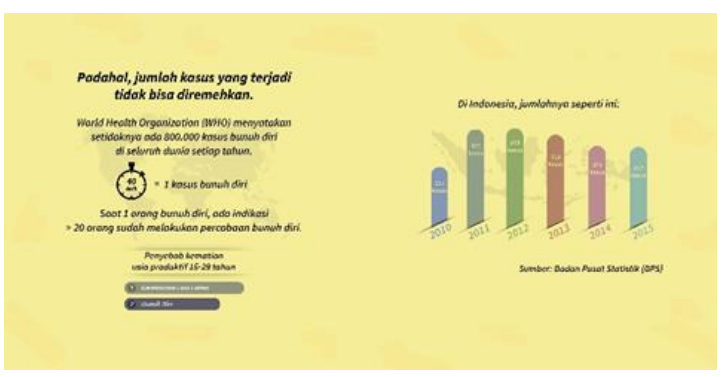

Gambar 5 : Desain halaman selanjutnya dalam bentuk fakta

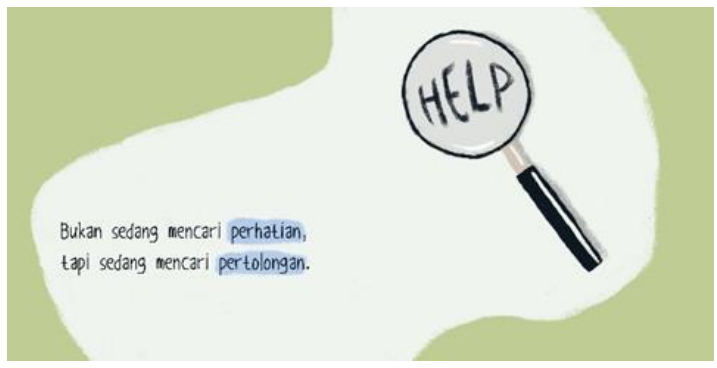

Gambar 6 : Desain halaman isi lain dalam bentuk slogan-slogan

\section{SIMPULAN DAN SARAN}

Perancangan media kampanye tentang pencegahan bunuh diri ini, dibuat untuk mendukung program kampanye sebuah komunitas; Ijinkan Dirimu. Dengan mempertimbangkan rentang usia layanan, maka ditentukan bahwa media yang digunakan adalah media sosial.

Oleh sebab itu, media kampanye yang dirancang adalah berupa isi media sosial tersebut. Perancangan yang dilakukan ini kemudian berhasil menciptakan beberapa halaman isi yang kemudian digunakan oleh komunitas tersebut.

Untuk kepentingan lebih jauh, disarankan agar komunitas Ijinkan Dirimu, mengelaborasi substansi kampanye dan memanfaatkan desain komunikasi visual untuk menciptakan isi media sosial mereka. Termasuk berkolaborasi dalam rancangan media lain bagi acara-acara seminar atau sosialisasi massal.

\section{DAFTAR PUSTAKA}

Ardian, J. (2019) Bunuh Diri (Saya Nggak Pamit). www.youtube.com. Available at: https://www.youtube.com/watch? $\mathrm{v}=\mathrm{ONp}$ 3PTWKPIc.

Damayanti, S., Putra, D. K. S. and Mayangsari, I. D. (2016) 'Framing Analysis of News About Jakarta' S Northern Coast Reclamation on', $e$ Proceeding of Management, 3(3), pp. 3928-3936. Available at: https://libraryeproceeding.telkomuniversi ty.ac.id/index.php/management/article/vi ew/3785.

Dirgayunita, A. (2016) 'Depresi: Ciri, Penyebab dan Penangannya', Journal An-Nafs: Kajian Penelitian Psikologi, 1(1), pp. 1-14. doi: 10.33367/psi.v1i1.235.

Frankel, L. and Racine, M. (2010) 'The Complex Field of Research: for Design, through Design, and about Design', International Conference of the Design Research Society, pp. 1-12.

Mukarromah, L. and Nuqul, F. L. (2014)

'Dinamika Psikologis pada Pelaku Percobaan Bunuh Diri', Psikoislamika : Jurnal Psikologi dan Psikologi Islam, 11(2). doi: 10.18860/psi.v11i2.6387.

Ramadhan, G. (2019) 'Cibiran \& Stigma Jadi Alasan Masyarakat Permisif Sikapi Bunuh Diri', Jakarta, 1 February. Available at: https://tirto.id/cibiranstigma-jadi-alasan-masyarakat-permisifsikapi-bunuh-diri-dfF1 (Accessed: 3 October 2020).

Setyanto, D. W. and Adiwibawa, B. A. P. (2018) 'Perancangan Fotografi Karakter Heroine Dalam Balutan Warna Merah', in Panitia Seminar Nasional Seni dan Desain (ed.) Seminar Seni dan Desain 
Nimas Sekararum, Bernardus Andang Prasetya Adiwibawa, PERANCANGAN MEDIA KAMPANYE TENTANG PENCEGAHAN BUNUH DIRI

2018 Konvergensi Keilmuan Seni Rupa dan Desain Pada Era 4.0 Universitas Negeri Surabaya. Surabaya: Jurusan Seni Rupa Fakultas Bahasa dan Seni Universitas Negeri Surabaya, pp. 78-83.

Setyanto, D. W. and Adiwibawa, B. A. P. (2019) 'Perancangan Infografis Instruksional Kampanye R3', in Panitia Seminar Nasional Pakar ke-2 2019 (ed.) Seminar Nasional Pakar ke 2 Tahun 2019. Jakarta: Lemlit Universitas Trisakti, pp. 1-7.

Yusdiansyah, I. (2018) 'Kasus Bunuh Diri Masih Tinggi, Titah Rahayu: Yuk! Cegah dengan Cara ini', PT Banten Muda Kreasindo, 22 September. Available at: https://www.biem.co/read/2018/09/22/27 325/kasus-bunuh-diri-masih-tinggi-titahrahayu-yuk-cegah-dengan-cara-ini/ (Accessed: 3 October 2020). 